\title{
Correlation Study Between Volume and Overall Acceptability of Cake with Properties of Hard Wheat Flour
}

\author{
Hanee Al-Dmoor \\ Department of Nutrition and Food Processing, \\ Faculty of Agricultural Technology, Al-Balqa Applied University, Al-Salt, Jordan
}

Received 2013-06-03, Revised 2013-07-04; Accepted 2013-07-06

\begin{abstract}
The most important factor in cakes making is the availability of soft wheat flour. Sometimes cake flour is producing by milling hard wheat because the shortage of soft wheat flour. The aim of this study is to identify a specification for production cake flour from hard wheat which gives a high quality of cake products. Protein $\%$, ash $\%$, wet gluten $\%$, dry gluten $\%$, gluten index, falling no, acidity $\%$, damaged starch, sedimentation values and particles size are 8.82, 0.5, 24.1, 8.44, 97.65, 310.3, 0.15, 7.71,72.7 and 10.07 respectively. The development time, stability, elasticity, softening, water absorption, resistance, extensibility and $\mathrm{R}$ : F values for dough are 1.35, 3.1, 102, 89.4, 57.73, 98.6, 357, 155 and 2.31 respectively. The average of cakes volume is 711 c.c and overall acceptability is 7.55 of 9 hedonic scales. Both of cake volume and overall acceptability of sensory evaluation test correlate positively $(\mathrm{p}<0.005)$ with protein and gluten content, sedimentation rate and extensograph parameters which give an indication about hard wheat cake flour could be substituted for soft wheat flour. Cake producers should apply a special treatment to improve the quality of cake.
\end{abstract}

Keywords: Cake, Flour, Baking, Quality, Rheology, Property

\section{INTRODUCTION}

Cake flour is well-defined, low ash and low protein content produced for best cake bake performance by milling of soft wheat grains that highly refined flour which is extracted from the centre of the kernel of wheat (Al-Dmoor, 2013). Soft wheat flours are generally low water absorption which doesn't require severe mixing batter for resulting products possess qualities such as tenderness, softness, crispness and good texture (Edmund and Perry, 2008). It is known the general specifications for typical for cake flour include; moisture at $13.50 \pm 0.5 \%$, protein at $8.00 \pm 0.5 \%$, ash content of $0.35 \pm 0.05 \%$. The best cakes are produced from lowprotein flour $(7-9 \%)$, clean which is close as possible to being pure endosperm, with small particle size and little starch damage, which will blend easily to give a smooth cake batter and tender cakes (Cauvain and Young, 2006; Edmund and Perry, 2008).
Hard wheat yields strong flour with higher protein content, is commonly used in the production of yeast leavened bakery products such as bread, whereas the soft flour of weak protein is found appropriate for the production of cookies, cakes, biscuits and crackers. Weak flour proteins do not form constant gluten network when flour is mixed with water due to lesser quantity and basic quality characteristics of gluten proteins in weak flour (Al-Dmoor, 2013). The conditions of dough preparation for soft wheat products such as low levels of water addition and higher amounts of sugar and fat in the formulation with low energy inputs favor dough preparation that is crumbly and extensible but lacks strength and elasticity (Sakiyan et al., 2004). Dough with such characteristics extends more when subjected to higher temperature in the baking and more numbers of biscuits are obtained from a given mass of dough (Sahi and Alava, 2003). 
Gluten provides the structure in baked goods which affects by the quality and quantity of gluten. Higher amounts of gluten proteins are not desirable for cake production because large amounts of gluten proteins prevent spread of dough and hampers molding of dough to specific dimension and shape (Al-Dmoor, 2013). The larger amounts of gluten proteins make the dough stronger and elastic that contracts/recoils after sheet formation. The glutenin proteins are held responsible for the strength and elastic nature of dough or gluten. These proteins favor gas retention and hence volume of bakery products. Gliadin proteins are smaller and globular in nature and are credited with less surface areas for interaction with other flour constituents and hence these proteins make the dough more extensible (Sahi and Alava, 2003; Sakiyan et al., 2004).

Starch has also been shown to affect the cakes quality. Gelatinization of starch during baking plays important role in producing internal texture of cakes. Starch also contributes to the crust color formation. Increasing starch content in wheat flour increases the diameter and spread factor of cakes. This may be due to the dilution of gluten by increase in level of starch in the dough. Lesser amount or dilution of gluten improves the extensibility and spread of dough during baking (Sumnu and Sahin, 2008).

Damaged starch is one that has been physically damaged during the wheat milling process which differs between flours milled from different wheat varieties. For example milling of a hard variety requires more energy and thus severity of grinding results in higher percentage of damaged starch in hard wheat flours. By contrast, lesser energy is needed to grind soft wheat grains to desired particle size flour and hence the soft wheat flour generally has lesser percentage of damaged starch. Therefore, the proportion of damaged starch in flour is of great importance to the rheological and baking quality of the flour (Sahi and Alava, 2003; Sumnu and Sahin, 2008).

A good quality cake should have high volume with a fine uniform moist crumb. Starch gelatinization, protein denaturation together with carbon dioxide formation gives cake its porous, soft structure. The degree of expansion is dependent on the viscosity of the batter. If the batter is thick, it would be difficult for the air bubbles to escape, which would result in a high volume cake (Kim and Walker, 1992).

Cake flour is generally treated with different methods such as heating, chlorine or ozone treatments, addition of xanthan gum, L-cysteine, hydrogen peroxide and peroxidase to enhance its baking potential and produce cakes with volumes that were slightly greater than those of cakes made with the chlorinated control flour (Thomasson et al., 1995; Donelson et al., 2000; Dubois et al., 2006; Finnie et al., 2006). The purpose of this study is to categorize a specific standard specification for production and using cake flour produced from hard wheat which gives a high quality of cake products.

\section{MATERIALS AND METHODS}

\subsection{Selection of the Extraction Rate}

Three samples of hard wheat grains were milled by five extraction rates; 50, 60, 70, 80 and 90\%. Moisture, protein, starch and ash determined to evaluate the variation between flour components according to specific rates of extractions.

\subsection{Flour Analysis}

Moisture of flour was determined by AACC 4415A method. Ash determined by AACC 08-3 method. Protein of flour was determined by AACC 46-13 Micro-Kjeldahl method.Starch determined by using perchloric acid/anthrone reagent. Onto the dried pellet which the preparation was above described, $40 \mathrm{~mL}$ of $35 \%$ perchloric acid were added and the samples were boiled for $2 \mathrm{~min}$, cooled and the final volume made up to $100 \mathrm{~mL}$ with perchloric acid. A standard of soluble starch from BDH was also run. $0.5 \mathrm{~mL}$ of suitably diluted starch solution was pipetted into test tubes and $5 \mathrm{ml}$ of anthrone reagent was added. The tubes were then placed in boiling water for $12 \mathrm{~min}$, cooled and the absorbance read at $625 \mathrm{~nm}$. Wet, dry and Gluten Index determined by Glutomatic Method (Young, 2009). Starch damage determined by AACC Method 76-31 (Young, 2009). Sedimentation values were determined by using (AACC method 56-60.01). Titratable acidity determined by AACC Method 0231.01(AACC, 2000).

Measurements of water absorption \%, peak time, dough stability and mixing tolerance index MTI were determined by using a Farinograph (Brabender OHG, Duisburg, Germany) according to AACC 54-21 method, constant flour weight procedure. Dough extensibility, maximum resistance to an extension, Area of Extensogram and the Ratio were determined using an Extensograph (Brabender OHG, Duisburg, Germany) according to AACC 54-10 method. 


\subsection{Cake Flour Production}

Cakes made from soft wheat flour which chemical and physical properties are well appropriate to the production of cakes by producers in high quality specifications and desirable to the consumer. In some countries that do not have the presence of soft wheat flour. Cake flour produced from milling of hard wheat under various trade names. The production of cake flour depends on practical experience of miller, extraction rate, particle size of flour and other laboratory tests.

\subsection{Cake Making}

The ingredients used were flour (300 g), egg (300 g), sugar (250 g), milk powder (30 g), shortening (200 $\mathrm{ml})$, emulsifier $(20 \mathrm{~g})$ and water $(60 \mathrm{~mL})$. Creaming mixing procedure was used. All ingredients except for the flour and milk were mixed for 5 min' using a mixer, after addition of the milk and flour, the mixing process was continued for $3 \mathrm{~min}$ at speed 8 . Individual $150 \mathrm{~mm}$ diameter, $50 \mathrm{~mm}$ height, metallic, butter coated pans were filled with $150 \mathrm{~g}$ of cake batter and baked in an electric oven at $250^{\circ} \mathrm{C}$ for $20 \mathrm{~min}$. Six cakes of each batter were baked. Three were chosen for volume analysis and three for sensory evaluation measurement. After baking, the cakes were removed from the pans, left for $1 \mathrm{~h}$ at room temperature to cool and then packed hermetically in plastic bags to prevent drying. Analysis of cakes was performed after $24 \mathrm{~h}$ storage at room temperature.

\subsection{Cake Volume}

Cake volumes were measured by using the rape seed displacement in the AACC method.

\subsection{Sensory Evaluation}

Cakes were evaluated by 60 untrained panelists for overall acceptability using a hedonic rating test was also performed to assess the degree of acceptability of cakes. The taste panelists were asked to rate the sample for color, flavor, texture and overall acceptability on a 1-9 point scale where $1=$ dislike extremely; 2 = dislike very much; 3 dislike moderately; $4=$ dislike slightly; $5=$ neither like nor dislike; $6=$ like slightly; $7=$ like moderately; $8=1$ ike very much and $9=$ like extremely (Lawless and Hildegarde, 1999).

\subsection{Statistical Analyses}

Values in the text and tables are expressed as Means \pm SD. Experiments were performed in three replicates and the data analyses were performed using SAS software (SAS, 2008). LSD tests for significant differences at $\mathrm{p} \leq 0.05$ among the wheat varieties.

\section{RESULTS}

\subsection{Extraction Rate}

Table 1 displays the flour components variations according to specific rates extractions of flour hard wheat. Table 2 shows some properties of cake flour of the studied samples of hard wheat. The average results of protein $\%$, ash $\%$, wet gluten $\%$, dry gluten $\%$, gluten index,falling no, acidity $\%$, damaged starch, sedimentation values and particles size are 8.82, 0.5, $24.1,8.44,97.65,310.3,0.15,7.71,72.7$ and 10.07 respectively. Table 3 shows some rheological properties of the studied samples of hard wheat. The average results of the development time, stability, elasticity, softening, water absorption, resistance, extensibility and $\mathrm{R}$ : $\mathrm{F}$ for dough is $1.35,3.1,102,89.4,57.73,98.6$, 357,155 and 2.31 respectively.

\subsection{Cake Volume}

The effects of using the 10 studied samples on the cake volume were evaluated and the results are presented in Table 4. The average of measurements is 711.1 cubic centimetres and significantly affected to volume of cakes. It was found that the lowest volume was achieved in sample 1 where the highest cake volume was shown in sample 5.

\subsection{Sensory Evaluation}

Table 4 shows the sensory scores reported by sensory 60 panellists of a 1-9 point scale using a hedonic rating to evaluate the overall acceptability of the cake samples. The overall acceptability was affected significantly $(p<0.05)$ for wheat flour in the cake samples as shown in Table 5. The highest value was 8.3 achieved in sample 6 where the lowest value was 6.8 found in sample 1 while the average of overall acceptability is 7.55 which mean the medium between like moderately and 1ike very much. Table 6 shows the correlation between the cake volume and overall acceptability with some properties of cake flour of hard wheat.

The results show both of cake volume and overall acceptability of sensory evaluation test correlate positively $(\mathrm{p}<0.005)$ with sedimentation rate. 
Table 1. Hard wheat flour components against different rates of extractions ${ }^{*}$

\begin{tabular}{llllll}
\hline Component & $50 \%$ Extraction & $60 \%$ Extraction & $70 \%$ Extraction & $80 \%$ Extraction & $90 \%$ Extraction \\
\hline Moisture & $13.6 \pm 0.3^{\mathrm{b}^{* *}}$ & $14 \pm 0.5^{\mathrm{a}}$ & $14 \pm 0.4^{\mathrm{a}}$ & $14 \pm 0.2^{\mathrm{a}}$ & $14 \pm 0.4^{\mathrm{a}}$ \\
Proteins & $7.8 \pm 0.4^{\mathrm{a}}$ & $8.2 \pm 0.5^{\mathrm{a}}$ & $10.6 \pm 0.3^{\mathrm{b}}$ & $11.4 \pm 0.4^{\mathrm{c}}$ & $12.3 \pm 0.4^{\mathrm{c}}$ \\
Starch & $73 \pm 2^{\mathrm{a}}$ & $71 \pm 1.8^{\mathrm{a}}$ & $70 \pm 2^{\mathrm{a}}$ & $66 \pm 2.2^{\mathrm{b}}$ & $64 \pm 1.6^{\mathrm{b}}$ \\
Ash & $0.41 \pm 0.06^{\mathrm{a}}$ & $0.54 \pm 0.05^{\mathrm{b}}$ & $0.72 \pm 0.03^{\mathrm{c}}$ & $0.86 \pm 0.03^{\mathrm{d}}$ & $0.95 \pm 0.04^{\mathrm{c}}$ \\
\hline
\end{tabular}

*Average of three samples \pm SD

**Means within rows with different letters significantly different according to LSD at $\mathrm{p} \leq 0.05$

Table 2. Some properties of cake flour of hard wheat

\begin{tabular}{|c|c|c|c|c|c|c|c|c|c|c|c|c|}
\hline Sample & $\begin{array}{l}\text { Extraction } \\
\text { rate }(\%)\end{array}$ & $\begin{array}{l}\text { Moisture } \\
(\%)\end{array}$ & $\begin{array}{l}\text { Protein } \\
(\%)\end{array}$ & Ash \% & $\begin{array}{l}\text { Wet } \\
\text { gluten }(\%)\end{array}$ & $\begin{array}{l}\text { Dry } \\
\text { gluten }(\%)\end{array}$ & $\begin{array}{l}\text { Gluten } \\
\text { index }\end{array}$ & $\begin{array}{l}\text { Falling } \\
\text { no }\end{array}$ & $\begin{array}{l}\text { Acidity } \\
(\%)\end{array}$ & $\begin{array}{l}\text { Damaged } \\
\text { starch }\end{array}$ & $\begin{array}{l}\text { Sedimentation } \\
\text { values }\end{array}$ & $\begin{array}{l}\text { Particles } \\
\text { size }\end{array}$ \\
\hline $\mathrm{WF}_{1}$ & $51 \pm 2.2^{\mathrm{a}^{* *}}$ & $14 \pm 0.6^{\mathrm{a}}$ & $8.5 \pm 0.3^{\mathrm{a}}$ & $.5 \pm 0.04^{\mathrm{a}}$ & $23.5 \pm 1.2^{\mathrm{a}}$ & $8.2 \pm 0.5^{\mathrm{a}}$ & $98.9 \pm 0.2^{\mathrm{a}}$ & $358 \pm 3^{\mathrm{c}}$ & $0.15 \pm 0.02^{\mathrm{a}}$ & $7.7 \pm 1.4^{\mathrm{a}}$ & $60 \pm 5^{\mathrm{a}}$ & $10.2 \pm 0.6^{\mathrm{a}}$ \\
\hline $\mathrm{HWF}_{2}$ & $50 \pm 2.4^{\mathrm{a}}$ & $14 \pm 0.3^{\mathrm{a}}$ & $8.6 \pm 0.4^{\mathrm{a}}$ & $0.48 \pm 0.02^{\mathrm{a}}$ & $23.5 \pm 1.4^{\mathrm{a}}$ & $8.3 \pm 06^{\mathrm{a}}$ & $98.9 \pm 0.1^{\mathrm{a}}$ & $370 \pm 8^{c}$ & $0.15 \pm 0.04^{\mathrm{a}}$ & & & \\
\hline $\mathrm{HWF}_{3}$ & $52 \pm 3.1^{\mathrm{a}}$ & $14.2 \pm 0.5^{\mathrm{a}}$ & $8.7 \pm 0.2^{\mathrm{a}}$ & $0.46 \pm 0.03^{\mathrm{a}}$ & $21.5 \pm 1.4^{\mathrm{a}}$ & $7.6 \pm 0.4^{\mathrm{a}}$ & $98.9 \pm 0.3^{\mathrm{a}}$ & $395 \pm 5 d$ & $0.1 \pm 0.05^{\mathrm{a}}$ & $7.2 \pm 1.1^{\mathrm{a}}$ & $71 \pm 7^{b}$ & $9.7 \pm 0.2^{\mathrm{a}}$ \\
\hline $\mathrm{HWF}_{4}$ & $52 \pm 2.4^{\mathrm{a}}$ & $14 \pm 0.6^{\mathrm{a}}$ & $8.6 \pm 0.5^{\mathrm{a}}$ & $0.46 \pm 0.05^{\mathrm{a}}$ & $23.5 \pm 1.0^{\mathrm{a}}$ & $8.4 \pm 0.3^{\mathrm{a}}$ & $98.9 \pm 0.2^{\mathrm{a}}$ & $350 \pm 5^{\mathrm{c}}$ & $0.15 \pm 0.06^{\mathrm{a}}$ & $8.1 \pm 0.6^{\mathrm{a}}$ & $72 \pm 4^{b}$ & $10.3 \pm 0.4^{\mathrm{a}}$ \\
\hline $\mathrm{HWF}_{5}$ & & $13.8 \pm 0.4^{\mathrm{a}}$ & $9.5 \pm 0.3^{\mathrm{a}}$ & $0.54 \pm 0.06^{\mathrm{a}}$ & & & & & $0.2 \pm$ & & & $10.1 \pm 0.6^{\mathrm{a}}$ \\
\hline $\mathrm{HWF}_{6}$ & $51 \pm 1$ & $14 \pm 0.8^{\mathrm{a}}$ & $8.7 \pm 0.3^{\mathrm{a}}$ & $0.53 \pm 0.07^{\mathrm{a}}$ & $24.9 \pm 0.7^{\mathrm{a}}$ & $8.5 \pm 0.4^{\mathrm{a}}$ & $99 \pm 0.2^{\mathrm{a}}$ & $205 \pm 5^{\mathrm{a}}$ & $0.15 \pm 0.03^{\mathrm{a}}$ & $7.7 \pm 1.2^{\mathrm{a}}$ & $74 \pm 3^{b}$ & $9.9 \pm 0.5^{\mathrm{a}}$ \\
\hline $\mathrm{HWF}_{7}$ & $52 \pm 2$ & $14.5 \pm 0.6^{\mathrm{a}}$ & $9.4 \pm 0.5^{\mathrm{a}}$ & $0.53 \pm 0.01^{\mathrm{a}}$ & $26.1 \pm 1.1^{\mathrm{a}}$ & $9.3 \pm 0.6^{\mathrm{b}}$ & $98.9 \pm 0.4^{\mathrm{a}}$ & $210 \pm 8^{\mathrm{a}}$ & $0.15 \pm 0.02^{\mathrm{a}}$ & $8.2 \pm 0.9^{\mathrm{a}}$ & $74 \pm 7^{b}$ & $9.8 \pm 0.2^{\mathrm{a}}$ \\
\hline $\mathrm{HWF}_{8}$ & & & $9.2 \pm 0.1^{\mathrm{a}}$ & $0.5 \pm 0.03^{\mathrm{a}}$ & $24.3 \pm 1.4^{\mathrm{a}}$ & & & $300 \pm 10^{\mathrm{b}}$ & $0.15 \pm 0.02^{\mathrm{a}}$ & $8 \pm 0.5^{\mathrm{a}}$ & & $10.3 \pm 0.1^{\mathrm{a}}$ \\
\hline $\mathrm{HWF}_{9}$ & $52 \pm 1.3^{\mathrm{a}}$ & $14 \pm 0.3^{\mathrm{a}}$ & $8.5 \pm 0.2^{\mathrm{a}}$ & $0.47 \pm 0.03^{\mathrm{a}}$ & $24.6 \pm 1.5^{\mathrm{a}}$ & $8.2 \pm 0.4^{\mathrm{a}}$ & $92 \pm 0.1^{\mathrm{a}}$ & $420 \pm 6 \mathrm{~d}$ & $0.2 \pm 0.01^{\mathrm{a}}$ & $7.5 \pm 0.7^{\mathrm{a}}$ & $71 \pm 3^{b}$ & $10.1 \pm 09^{\mathrm{a}}$ \\
\hline $\mathrm{HWF}_{10}$ & $53 \pm 1.2^{\mathrm{a}}$ & $13.8 \pm 0.4^{\mathrm{a}}$ & $8.5 \pm 0 .^{\mathrm{a}}$ & $0.52 \pm 0.01^{\mathrm{a}}$ & $23 \pm 1.2^{\mathrm{a}}$ & $7.8 \pm 0.1^{\mathrm{a}}$ & $93 \pm 0.1^{\mathrm{a}}$ & $300 \pm 5^{\mathrm{b}}$ & $0.15 \pm 0.05^{\mathrm{a}}$ & $7.6 \pm 0.8^{\mathrm{a}}$ & $66 \pm 4^{\mathrm{a}}$ & $9.9 \pm 0.2^{\mathrm{a}}$ \\
\hline Average & 51.66 & 14 & 8.82 & 0.5 & 24.1 & 8.44 & 97.65 & 310.3 & 0.15 & 7.71 & 72.7 & 10.07 \\
\hline
\end{tabular}

*Average of three samples \pm SD

**Means within rows with different letters significantly different according to LSD at $\mathrm{p} \leq 0.05$

Table 3. Some rheological properties of hard wheat cake flour*

\begin{tabular}{|c|c|c|c|c|c|c|c|c|}
\hline \multirow[b]{2}{*}{ Sample } & \multicolumn{5}{|l|}{ Farinograph } & \multicolumn{3}{|c|}{ Extensograph } \\
\hline & $\begin{array}{l}\text { Development } \\
\text { time }\end{array}$ & Stability & Elasticity & Softening & $\begin{array}{l}\text { Water } \\
\text { absorption }\end{array}$ & Resistance & Extensibility & $\mathrm{R}: \mathrm{E}$ \\
\hline $\mathrm{HWF}_{1}$ & $1.5 \pm 0.1^{\mathrm{b}^{* *}}$ & $4 \pm 0.4^{b}$ & $100 \pm 10^{b}$ & $80 \pm 10^{a}$ & $57 \pm 1^{\mathrm{a}}$ & $300 \pm 10^{b}$ & $140 \pm 3^{\mathrm{a}}$ & $2.1 \pm 0.1^{\mathrm{a}}$ \\
\hline $\mathrm{HWF}_{2}$ & $1.5 \pm 0.1^{\mathrm{b}}$ & $3.5 \pm 0.3^{b}$ & $110 \pm 10^{b c}$ & $80 \pm 10^{\mathrm{a}}$ & $57 \pm 2^{a}$ & $320 \pm 10^{b}$ & $163 \pm 4^{b}$ & $1.96 \pm 0.08^{\mathrm{a}}$ \\
\hline $\mathrm{HWF}_{3}$ & $1.5 \pm 0.1^{\mathrm{b}}$ & $2.5 \pm 0.4^{\mathrm{a}}$ & $80 \pm 10^{\mathrm{a}}$ & $100 \pm 10^{b}$ & $57.5 \pm 2^{\mathrm{ab}}$ & $270 \pm 10^{\mathrm{a}}$ & $150 \pm 5^{\mathrm{a}}$ & $1.8 \pm 0.1^{\mathrm{a}}$ \\
\hline $\mathrm{HWF}_{4}$ & $1.5 \pm 0.1^{\mathrm{b}}$ & $3.5 \pm 0.3^{b}$ & $90 \pm 10^{\mathrm{a}}$ & $100 \pm 10^{b}$ & $58 \pm 1^{b}$ & $380 \pm 10^{c}$ & $150 \pm 3^{a}$ & $2.5 \pm 0.1$ \\
\hline $\mathrm{HWF}_{5}$ & $1.5 \pm 0.1^{b}$ & $2.5 \pm 0.2^{\mathrm{a}}$ & $100 \pm 10^{b}$ & $120 \pm 10^{\mathrm{c}}$ & $56 \pm 2^{a}$ & $450 \pm 10^{\mathrm{d}}$ & $170 \pm 3^{b}$ & $2.6 \pm 0.2^{b}$ \\
\hline $\mathrm{HWF}_{6}$ & $1.5 \pm 0.1^{\mathrm{b}}$ & $2.5 \pm 0.2^{\mathrm{a}}$ & $120 \pm 10^{c}$ & $110 \pm 10^{c}$ & $56.2 \pm 1^{\mathrm{a}}$ & $440 \pm 10^{\mathrm{d}}$ & $170 \pm 2^{b}$ & $2.9 \pm 0.2^{\mathrm{b}}$ \\
\hline $\mathrm{HWF}_{7}$ & $1 \pm 0.1^{\mathrm{a}}$ & $3.5 \pm 0.5^{b}$ & $120 \pm 10^{c}$ & $100 \pm 10^{b}$ & $55.6 \pm 1^{\mathrm{a}}$ & $450 \pm 10$ & $167 \pm 1^{b}$ & $2.7 \pm 0.1^{b}$ \\
\hline $\mathrm{HWF}_{8}$ & $1 \pm 0.1^{\mathrm{a}}$ & $2.5 \pm 0.1^{\mathrm{a}}$ & $80 \pm 10^{\mathrm{a}}$ & $100 \pm 10^{b}$ & $60 \pm 3^{b}$ & $320 \pm 10^{b}$ & $145 \pm 2^{\mathrm{a}}$ & $2.2 \pm 0.06^{\mathrm{a}}$ \\
\hline $\mathrm{HWF}_{9}$ & $1.5 \pm 0.1^{\mathrm{b}}$ & $2.5 \pm 0.3^{\mathrm{a}}$ & $100 \pm 10^{b}$ & $100 \pm 10^{b}$ & $60 \pm 3^{b}$ & $320 \pm 10^{b}$ & $145 \pm 1^{\mathrm{a}}$ & $2.2 \pm 0.1^{\mathrm{a}}$ \\
\hline $\mathrm{HWF}_{10}$ & $1 \pm 0.1^{\mathrm{a}}$ & $4 \pm 0.6^{\mathrm{b}}$ & $120 \pm 10^{c}$ & $100 \pm 10^{b}$ & $60 \pm 3^{b}$ & $320 \pm 10^{b}$ & $150 \pm 3^{a}$ & $2.1 \pm 0.2^{\mathrm{a}}$ \\
\hline Average & 1.35 & 3.1 & 102 & 89.4 & 57.73 & 357 & 155 & 2.31 \\
\hline
\end{tabular}

*Average of three samples \pm SD

**Means within rows with different letters significantly different according to LSD at $\mathrm{p} \leq 0.05$

Although, it was found both of cake volume and overall acceptability correlate positively $(\mathrm{p}<0.005)$ with softening of dough which determined with farinograph. In addition to the resistance, extensibility and R: E values of dough that measured via extensograph parameters correlate positively $(\mathrm{p}<0.005)$ with cake volume and overall acceptability of sensory evaluation. To the contrary, farinograph dough stability parameter values were negatively correlated $(\mathrm{p}<0.005)$ with both of the overall panelists acceptability and cake volume of hard wheat cake flour. The results show all of water absorption of flour, development time and elasticity of dough which determined with farinograph have not significant correlation $\mathrm{p}<0.005)$ with both of cake volume and overall acceptability of cake flour of hard wheat. 
Table 4. The volume and overall acceptability of cake

\begin{tabular}{lll}
\hline Sample & Volume (c.c)* & Average of overall acceptability** \\
\hline $\mathrm{HWF}_{1}$ & $667 \pm 5^{\mathrm{a} * * *}$ & $6.8^{\mathrm{a}}$ \\
$\mathrm{HWF}_{2}$ & $689 \pm 4^{\mathrm{a}}$ & $6.9^{\mathrm{a}}$ \\
$\mathrm{HWF}_{3}$ & $690 \pm 3^{\mathrm{a}}$ & $7.3^{\mathrm{a}}$ \\
$\mathrm{HWF}_{4}$ & $708 \pm 6^{\mathrm{a}}$ & $7.5^{\mathrm{a}}$ \\
$\mathrm{HWF}_{5}$ & $750 \pm 7^{\mathrm{b}}$ & $8.2^{\mathrm{b}}$ \\
$\mathrm{HWF}_{6}$ & $740 \pm 5^{\mathrm{b}}$ & $8.3^{\mathrm{b}}$ \\
$\mathrm{HWF}_{7}$ & $745 \pm 7^{\mathrm{b}}$ & $8.1^{\mathrm{b}}$ \\
$\mathrm{HWF}_{8}$ & $753 \pm 3^{\mathrm{b}}$ & $7.9^{\mathrm{b}}$ \\
$\mathrm{HWF}_{9}$ & $697 \pm 5^{\mathrm{a}}$ & $7.2^{\mathrm{a}}$ \\
$\mathrm{HWF}_{10}$ & $672 \pm 5^{\mathrm{a}}$ & $7.3^{\mathrm{a}}$ \\
Average & 711.1 & 7.55 \\
\hline
\end{tabular}

*Average of three samples \pm SD

**Average of 60 panelists of a 1-9 point scale using a hedonic rating test

***Means within rows with different letters significantly different according to LSD at $\mathrm{p} \leq 0.05$

Table 5. The correlation between the cake volume and overall acceptability with some properties of cake flour of hard wheat

\begin{tabular}{|c|c|c|c|c|c|c|c|c|c|c|}
\hline & Protein & Moisture & Ash & $\begin{array}{l}\text { Dry } \\
\text { Wet gluten }\end{array}$ & $\begin{array}{l}\text { Gluten } \\
\text { gluten }\end{array}$ & index & Falling no & Acidity & $\begin{array}{l}\text { Damaged } \\
\text { starch }\end{array}$ & $\begin{array}{l}\text { Particle } \\
\text { size }\end{array}$ \\
\hline Cake & $0.83909^{\mathrm{S}}$ & $0.00297^{\mathrm{NS}}$ & $0.49651^{\mathrm{NS}}$ & $0.73352^{\mathrm{S}}$ & $0.85051^{\mathrm{S}}$ & $0.44700^{\mathrm{NS}}$ & $-0.72534^{\mathrm{S}}$ & $0.27132^{\mathrm{NS}}$ & $0.50352^{\mathrm{S}}$ & $-0.04224^{\mathrm{NS}}$ \\
\hline volume & 0.00240 & 0.99350 & 0.14440 & 0.01580 & 0.00180 & 0.19530 & 0.01760 & 0.44830 & 0.13790 & 0.90780 \\
\hline Overall & $0.74433^{\mathrm{S}}$ & $0.03626^{\mathrm{NS}}$ & $0.64493^{\mathrm{S}}$ & $0.67808^{\mathrm{S}}$ & $0.69412^{\mathrm{S}}$ & $0.35032^{\mathrm{NS}}$ & $-0.86005^{\mathrm{S}}$ & $0.19859^{\mathrm{NS}}$ & $0.43042^{\mathrm{NS}}$ & $-0.32576^{\mathrm{NS}}$ \\
\hline Acceptability & 0.01350 & 0.92080 & 0.04410 & 0.03120 & 0.02600 & 0.32100 & 0.00140 & 0.58230 & 0.21440 & 0.35830 \\
\hline
\end{tabular}

${ }^{\text {NS Not Significant; S Significant at P-value }<0.005}$

Table 6. The correlation between the cake volume and overall acceptability with sedimentation rate and some rheological properties of hard wheat cake flour

\begin{tabular}{|c|c|c|c|c|c|c|c|c|c|}
\hline \multirow[t]{2}{*}{ Sedimentation } & \multicolumn{4}{|l|}{ Development } & \multicolumn{5}{|l|}{ Water } \\
\hline & Rate & time & Stability & Elasticity & Softening & absorption & Resistance & Extensibility & $\mathrm{R}: \mathrm{E}$ \\
\hline Cake & $0.69049^{\mathrm{S}}$ & $-0.25493^{\mathrm{NS}}$ & $-0.59179^{\mathrm{S}}$ & $-0.02859^{\mathrm{NS}}$ & $0.67012^{S}$ & $-0.30694^{\mathrm{NS}}$ & $0.72985^{\mathrm{S}}$ & $0.57594^{\mathrm{S}}$ & $0.70416^{\mathrm{S}}$ \\
\hline Volume & 0.02710 & 0.47720 & 0.07150 & 0.93750 & 0.03400 & 0.38830 & 0.01660 & 0.08140 & 0.02300 \\
\hline Overall & $0.76734^{\mathrm{S}}$ & $-0.27580^{\mathrm{NS}}$ & $-0.51373^{\mathrm{S}}$ & $0.17199^{\mathrm{NS}}$ & $0.83030^{\mathrm{S}}$ & $-0.35162^{\mathrm{NS}}$ & $0.82131^{\mathrm{S}}$ & $0.65771^{\mathrm{S}}$ & $0.81572^{\mathrm{S}}$ \\
\hline Acceptability & 0.00960 & 0.44050 & 0.12880 & 0.63470 & 0.00290 & 0.31910 & 0.00360 & 0.03870 & 0.00400 \\
\hline
\end{tabular}

${ }^{\mathrm{NS}}$ Not Significant; S Significant at P-value $<0.005$

\section{DISCUSSION}

The difference in the proportions of flour components sometimes have no significant but may lead to differences the rheological proportions of dough and in the final product characteristics. It was found no significant differences between proteins and starch at 50 and $60 \%$ while ash percentage values were significantly different and they near bye to soft wheat flour. Feasibly it is known the most important component in the production of cakes are gluten and starch properties that appear in gas retention, elasticity water absorption and so on. For cake flour 50\% mostly are applied in flour milling. These results give to investigator an indication to choose the $50 \%$ extraction rate to complete the study to identify a specification to use hard wheat flour for cake production.
The resulted values of the ten studied samples parade no significant differences at $\mathrm{p} \leq 0.05$ between protein, ash, wet gluten, dry gluten, gluten index, acidity, damaged starch and particles size except the sedimentation values and falling no were significantly different. Compared with what is known about soft wheat flour properties, the results obtained in Table 2 approaches to specification parameters for cake flour by milling soft wheat except wet and dry gluten, gluten index and sedimentation values.

The resulted values of the ten studied samples show significant differences at $\mathrm{p} \leq 0.05$ between these parameters which may explain by the rheological properties of hard wheat. Compared with the soft wheat flour properties, the results obtained by farinograph and extensograph were higher than to the specification parameters for cake flour by milling soft wheat. The 
rheological properties results in the Table 2 results explain the difficulties of using of hard wheat cake flour in cake making which cake producers is facing.

So that cake producers should apply different ways to solve this problem such as apply special treatments and additives used by the miller or producers of cake to improve the rheological properties cake flour and the final cake product manufactured from hard wheats.

The difference between these values of the cake volume of the samples examined were due to differences in the properties of the gluten, which was particularly evident in the previously mentioned tests such as sedimentation and rheological tests obtained by farinograph and extensograph.

The result suggested that cake flour of hard wheat could be substituted for soft wheat flour in cake production. For more excellency in the overall acceptability bakeries may apply a special treatment or adding suitable additives or improvers.

Both of cake volume and overall acceptability of sensory evaluation test correlate positively $(p<0.005)$ or influenced by protein and gluten content in flour. As expected, in hard wheat, there is a strong relationship between protein and gluten content and volume of backed products which effect quality of products. However, only ash showed a significant correlation with overall acceptability of sensory evaluation test correlate positively $(\mathrm{p}<0.005)$. To the contrary, both of falling number and particle size were negatively correlated $(\mathrm{p}<0.005)$ with the overall acceptability and cake volume. Results also showed that there is a moderate positively correlation $(p<0.005)$ between the damaged starches and cake volume while it has not significant correlation with overall acceptability of sensory evaluation test. Although, the results found all of moisture, gluten index, acidity and particle size of flour have not significant correlation $(p<0.005)$ with cake volume and overall acceptability of cake flour of hard wheat. However, it is seem the correlation values at $(p<0.005)$ for sedimentation rate and both of farinograph and extensograph parameters ranged between 0.65 to the 0.83 which are not high which give an indication about cake flour of hard wheat could be substituted for soft wheat flour in cake production. Therefore, I can say, the values of the correlation between hard wheat cake flour and cake quality can increase. So that cake producers should apply a special treatment or adding suitable additives or improvers to improve the quality of cake.

\section{CONCLUSION}

The study concluded the miller can produce flour with nearly percentage of soft wheat flour but the rheological properties aren't suitable for cake making or productions which are important for produce high quality cake. I recommend to use a way to improve or modify the strength of gluten by use food additives permitted for improving flour characteristics such as enzymes, reducing agents or heat treatments to alter the chemical bonds that affect intensity and strength of gluten, therefore affect the final size of the typical cake request and give internal and external structure typical cake request.

\section{ACKNOWLEDGEMENT}

Many thanks for Mu'tah university for given me the enough time to carry out this study within the sabbatical leave which granted to me from my university Al-Balqa applied university which always thanked. Many thanks for the Saudi Jordanian Ind. Dev. Co. in Jordan and Faculty For Factory (FFF) program for supporting this project.

\section{REFERENCES}

AACC, 2000. Approved Methods of the American Association of Cereal Chemists. 10th Edn., AACC, St. Paul, ISBN-10: 1891127128, pp: 1200.

Al-Dmoor, H.M., 2013. Cake flour: Functionality and quality. Europ. Scient. J., 9: 168-180.

Cauvain, S.P. and L.S. Young, 2006. Baked Products: Science, Technology and Practice. 1st Edn., WileyBlackwell, Oxford, ISBN-10: 1405127023, pp: 244.

Donelson, J.R., C.S. Gaines and P.L. Finney, 2000. Baking formula innovation to eliminate chlorine treatment of cake flour. Cereal Chem., 77: 53-57. DOI: 10.1094/CCHEM.2000.77.1.53

Dubois, M., C. Coste, A.G. Despres, T. Efstathiou and C. Nio et al., 2006. Safety of Oxygreen, an ozone treatment on wheat grains. Part 2. Is there a substantial equivalence between Oxygreen-treated wheat grains and untreated wheat grains. Food Additives Contaminants, 23: 1-15. PMID: 16393809

Edmund, J.T. and K.W. Perry, 2008. Soft Wheat Quality. In: Food Engineering Aspects of Baking Sweet Goods, Servet, G.S. and S. Serpil (Eds.), Taylor and Francis, Boca Raton, ISBN-10: 1420052772, pp: 1-30. 
Finnie, S.M., A.D. Bettge and C.F. Morris, 2006. Influence of flour chlorination and ingredient formulation on the quality attributes of pancakes. Cereal Chem., 83: 684-691. DOI: 10.1094/CC-830684

Kim, C.S. and C.E. Walker, 1992. Interactions between starches, sugars and emulsifiers in highratio cake model systems. Cereal Chem., 69: 206212.

Lawless, H.T. and H. Hildegarde, 1999. Sensory Evaluation of Food: Principles and Practices. 1st Edn., Springer, New York, ISBN-10: 083421752X, pp: 848.

Sahi, S.S. and J.M. Alava, 2003. Functionality of emulsifiers in sponge cake production. J. Sci. Food Agric., 83: 1419-1429. DOI: $10.1002 /$ jsfa. 1557
Sakiyan, O., G. Sumnu, S. Sahin and G. Bayram, 2004. Influence of fat content and emulsifier type on the rheological properties of cake batter. Eur. Food Res. Technol., 219: 635-638. DOI: 10.1007/s00217-004-1020-4

SAS, 2008. SAS User's Guide. SAS Institute Inc., Cary, NC. USA.

Sumnu, G. and S. Sahin, 2008. Food Engineering Aspects of Baking Sweet Goods. 1st Edn., Taylor and Francis, Boca Raton, ISBN-10: 1420052772, pp: 304.

Thomasson, C.A., R.A. Miller and R.C. Hoseney, 1995. Replacement of chlorine treatment for cake flour. Cereal Chem., 72: 616-620.

Young, L.S., 2009. The ICC Handbook of cereals, flour, dough and products: Methods, tests and applications. Q. Assurance Safety Crops Foods, 1: 74-74. DOI: $10.1111 / \mathrm{j} .1757-837 X .2009 .00017 . x$ 